\title{
Renal and splanchnic exchange of human biosynthetic C-peptide in Type 1 (insulin-dependent) diabetes mellitus
}

\author{
S.Sjöberg ${ }^{1}$ B.-L.Johansson ${ }^{2}$, J. Östman ${ }^{1}$ and J.Wahren ${ }^{2}$ \\ Departments of ${ }^{1}$ Medicine, ${ }^{2}$ Clinical Physiology, Huddinge Hospital, Huddinge and \\ Department of Clinical Physiology, Karolinska Hospital, Stockholm, Sweden
}

\begin{abstract}
Summary. Biosynthetic human C-peptide or $\mathrm{NaCl}$ $\left(154 \mathrm{mmol}^{-1^{-1}}\right)$ was given intravenously to 13 Type 1 (insulin-dependent) diabetic patients to determine the renal and splanchnic exchange of C-peptide. Catheters were inserted percutaneously into an artery and a renal and hepatic vein. Infusions of C-peptide were given for $60 \mathrm{~min}$ at two dose levels (5 and $30 \mathrm{pmol} \cdot \mathrm{kg}^{-1} \cdot \mathrm{min}^{-1}$ ). Insulin was infused throughout the study $\left(0.5 \mathrm{mU} \cdot \mathrm{kg}^{-1} \cdot \mathrm{min}^{-1}\right)$ and plasma glucose was kept constant by a variable glucose infusion. The regional blood flows were measured by indicator dilution techniques. In 11 of the 13 patients basal C-peptide levels were not detectable. The arterial steady-state C-peptide concentration was $0.81 \pm 0.10 \mathrm{nmol} \cdot 1^{-1}$ and $2.33 \pm 0.30 \mathrm{nmol} \cdot 1^{-1}$ at the low and high rate infusions, respectively. Renal uptake was $124 \pm 18 \mathrm{pmol} \cdot \mathrm{min}^{-1}$ at the low infusion corresponding to $39 \%$ of the infused amount. At the higher dose C-peptide infusion renal uptake increased to $155 \pm 21 \mathrm{pmol} \cdot \mathrm{min}^{-1}$ $(p<0.05)$. Urinary excretion of C-peptide was $7 \pm 2$ pmol- $\min ^{-1}$ at the low dose infusion and increased to $34 \pm 6$ pmol-
\end{abstract}

$\cdot \min ^{-1}$ at the high dose infusion $(p<0.01)$. The proportions of infused amount excreted were fairly constant and between $2 \%$ and $3 \%$. No net exchange of C-peptide was found across the splanchnic vascular bed. The rate of glucose infusion had to be increased by $35 \%$ during the low dose C-peptide, but not during $\mathrm{NaCl}$ infusion in order to maintain a constant plasma glucose concentration. Arterial plasma concentrations of noradrenaline increased by $15-25 \%$ during both C-peptide and $\mathrm{NaCl}$ infusions. It is concluded that in patients with Type 1 diabetes (a) the kidney is the primary site of C-peptide removal, (b) renal metabolism rather than urinary excretion is the dominating process for C-peptide elimination (c) the excreted proportions of an infused amount of C-peptide were fairly constant between $2 \%$ and $3 \%$ and (d) no hepatic C-peptide catabolism could be detected.

Key words: Glucose utilization, Type 1 (insulin-dependent) diabetes mellitus, human C-peptide, glucagon, renal uptake, hepatic uptake.
The metabolic fate of C-peptide, which is secreted by the Beta cell in equimolar amounts with insulin, is not fully established. However, it is known that the kidneys are important for C-peptide degradation $[1,2]$. That they play an important role in this respect is supported by the increase in plasma C-peptide levels found in uraemic patients [3]. No more than approximately $2-5 \%$ of the secreted C-peptide is excreted into the urine [5-6]. In contrast to insulin, approximately $50 \%$ of which is taken up by the liver [7], no hepatic uptake of C-peptide has been found in dogs [8]. It has therefore been suggested that measurements of plasma C-peptide in the fasting state or after glucagon stimulation may accurately reflect the Beta-cell secretory activity of insulin [9].

It has previously been suggested that $\mathrm{C}$-peptide is a biologically inert substance [10]. No insulin-like effects have been observed in an experimental study [11] or in non-diabetic subjects [12]. However, it has recently been reported that C-peptide may increase the glucose transport in muscle from non-diabetic subjects [13].

Renal and splanchnic exchange of C-peptide has to our knowledge not been studied in Type 1 (insulin-dependent) diabetic patients. Therefore, the present study was undertaken to examine the renal and splanchnic uptake of biosynthetic human C-peptide in Type 1 diabetic patients without detectable residual insulin secretory activity. The possible influence of C-peptide on glucose utilization, as well as the plasma concentrations of glucagon and catecholamines was also studied.

\section{Subjects and methods}

\section{Subjects}

A total of 14 Type 1 diabetic patients with an $\mathrm{HbA}_{1 \mathrm{c}}$ of $6.9 \pm 0.2 \%$, a mean age of 24 years (range 18-30 years) and a history of diabetes mellitus for 11 years (range 3-20 years) participated in the study, 
Table 1. Clinical data for patients participating in the C-peptide and/or $\mathrm{NaCl}\left(154 \mathrm{mmol} \cdot \mathrm{l}^{-1}\right)$ infusion study

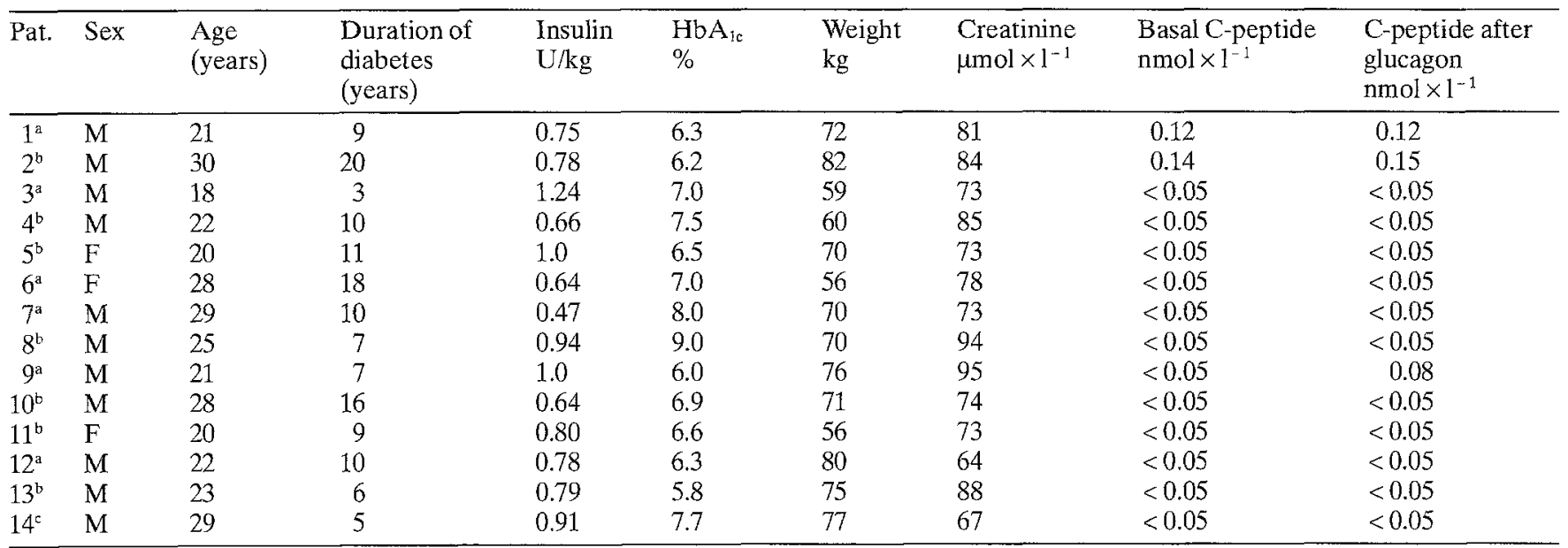

a C-peptide infusion and $\mathrm{NaCl}\left(154 \mathrm{mmol} \cdot \mathrm{L}^{-1}\right)$ infusion; ${ }^{b} \mathrm{C}$-peptide infusion only; ${ }^{c} \mathrm{NaCl}$ infusion study only

Clinical data for all the patients are given in Table 1. Thirteen patients received C-peptide infusions; six of these and one additional patient were given $\mathrm{NaCl}$ infusions. A period of 3-12 months elapsed between the two occasions in the seven patients who took part in both studies (Table 1).

Fundoscopic examination of all patients by an experienced ophthalmologist showed that only one had a mild retinopathy. Likewise nephropathy was not present, as shown by a negative test for albuminuria $\left(<30 \mu \mathrm{g} \cdot \mathrm{min}^{-1}\right)$. All 14 patients received regular treatment with short-acting insulin three to four times in the daytime and intermediate-acting insulin at bedtime. The patients were informed of the purpose and possible risks of the study before giving their informed consent to participate. The study protocol was approved by the local ethics committee.

\section{Methods}

C-peptide infusion. Biosynthetic human C-peptide (Batch CT7790$6 \mathrm{~B} 10 \mathrm{ml}$ vial containing $0.5 \mathrm{mg} \cdot \mathrm{ml}^{-1}$ ) was a gift from Eli Lilly (Indianapolis, Ind., USA). To minimize the adherence of C-peptide to syringes and tubing, $2 \mathrm{ml}$ of the patient's own blood was mixed with the C-peptide. $\mathrm{NaCl}\left(154 \mathrm{mmol} \cdot \mathrm{l}^{-1}\right)$ was then added to obtain the appropriate concentrations.

Infusion protocol. The patients were admitted to the hospital on the day before the study. The ordinary dose of insulin administered at bedtime was excluded on the day before the investigation. During the night, patients were given an i.v. infusion of insulin (approximately $1 \mathrm{U} \cdot \mathrm{h}^{-1}$ ) at a rate adjusted to ensure normoglycaemia in the morning. The patients were studied at 07.30 hours. The investigation was carried out in the fasting state, with the patient in the supine position. Under local anaesthesia one catheter was inserted percutaneously into the femoral vein and advanced under fluoroscopic control to a renal vein, another was placed in a right-sided hepatic vein and catheters were also introduced into a brachial artery and an antecubital vein.

In order to maintain adequate diuresis, water $\left(20 \mathrm{ml} \cdot \mathrm{kg}^{-1} \cdot \mathrm{h}^{-1}\right)$ was ingested in the basal state and thereafter $\left(10 \mathrm{ml} \cdot \mathrm{kg}^{-1} \cdot \mathrm{h}^{-1}\right)$ until the study was completed. A constant insulin infusion $(0.5 \mathrm{mU}$. $\left.\mathrm{kg}^{-1} \cdot \min ^{-1}\right)$ was given throughout the study. Glucose was administered simultaneously at rates adjusted to maintain plasma glucose levels at $5.6 \pm 0.6 \mathrm{mmol} \cdot 1^{-1}$, as indicated by measurements taken every 5 mins. At the start of the study a bolus dose of $p$-aminohippuric acid (PAH) was given corresponding to $9 \mathrm{mg} \cdot \mathrm{kg}^{-1}$. Thereafter simultaneous infusions of indocyanin green $\left(0.55 \mathrm{mg} \cdot \mathrm{min}^{-1}\right)$ and PAH (11.25 $\mathrm{mg} \cdot \mathrm{min}^{-1}$ ) were given to estimate the hepatic and renal blood flows. After $1.5 \mathrm{~h}$ in the basal state, a "low dose" of C-peptide was infused for $1 \mathrm{~h}$. This was started with a bolus of $25 \mathrm{ml} \cdot \mathrm{kg}^{-1} \cdot \mathrm{h}^{-1}$ during $1.5 \mathrm{~min}$ followed by $10 \mathrm{ml} \cdot \mathrm{kg}^{-1} \cdot \mathrm{h}^{-1}$ during another $6.5 \mathrm{~min}$ and finally $5 \mathrm{ml} \cdot \mathrm{kg}^{-1} \cdot \mathrm{h}^{-1}$ for $52 \mathrm{~min}$. The infusion rates were then increased six-fold during the following hour ("high dose" infusion period). Four blood samples were obtained during the last $20 \mathrm{~min}$ of each of the basal, low and high C-peptide infusion periods. Urine samples (spontaneous voiding) and blood samples for analysis of Cpeptide were collected at regular intervals throughout the study period.

Samples for C-peptide analysis were collected simultaneously from the hepatic and renal veins and the brachial artery. Samples for the determinations of glucose, glucagon and catecholamines were obtained from the brachial artery.

In four of the 13 patients given $C$-peptide and in one of the seven patients given $\mathrm{NaCl}$ the study had to be interrupted after one hour on the low-dose C-peptide or $\mathrm{NaCl}$ infusion. Moreover, catheters were not inserted in the liver and renal veins of two patients in the group infused with C-peptide.

Determinations of C-peptide, $H b A_{1 c}$, and glucose. The concentrations of $C$-peptide in plasma was measured in duplicate samples by a radioimmunological technique [14]. The detection limit of the assay was $0.05 \mathrm{nmol} \cdot 1^{-1}$. The procedure has been described in detail elsewhere [15]. Plasma glucose was measured by a glucose oxidase method (Beckman Glucostat, Calif., USA). HbA $1 \mathrm{c}$ was determined by a specificion exchange chromatography procedure at $22^{\circ} \mathrm{C}$, using commercially available microcolumns (Mono S HR 5/5, Pharmacia AB, Uppsala, Sweden) [16].

Determinations of plasma glucagon, catecholamines, etc. Glucagon was measured using antiserum (MILAB, Malmö, Sweden) and porcine ${ }^{125}$ I-glucagon (Novo, Copenhagen, Denmark) [17]. Catecholamines were measured by an HPLC technique [18]. Plasma free insulin was assayed with a radioimmunological technique after precipitation with polyethylene glycol (25\%) [19]. Serum non-esterified fatty acids (NEFA) were analysed by using a gas chromatographic method, as described by Hagenfeldt [20]. PAH was assessed in the blood by a modified Smith technique [21]. Indocyanin green was determined by a spectrophotometric method [22].

\section{Calculations of renal and splanchnic exchange of C-peptide}

Fractional renal extraction of C-peptide was calculated as the difference between the concentrations of C-peptide in the brachial artery and renal vein divided by the brachial artery concentration (\%). 
Table 2. Arterial C-peptide concentration, arterial-renal venous (A-RV) and arterial-hepatic venous (A-HV) C-peptide concentration differences, renal and hepatic extractions of $C$-peptide, renal and hepatic plasma flow in the patients studied before and during low- and high-dose C-peptide infusions. Mean \pm SEM are given

\begin{tabular}{|c|c|c|c|}
\hline & \multirow[b]{2}{*}{$\begin{array}{l}\text { Baseline } \\
\text { values } \\
n=13\end{array}$} & \multicolumn{2}{|c|}{ C-peptide infusion } \\
\hline & & $\begin{array}{l}\text { Low dose } \\
n=11\end{array}$ & $\begin{array}{l}\text { High dose } \\
n=7\end{array}$ \\
\hline Arterial C-peptide conc., $\mathrm{nmol} \cdot \overline{]^{-1}}$ & $<0.05$ & $0.81 \pm 0.10^{\mathrm{a}}$ & $2.33 \pm 0.30^{b}$ \\
\hline A-RV, nmol $\cdot 1^{-1}$ & $<0.05$ & $0.14 \pm 0.02$ & $0.17 \pm 0.03$ \\
\hline A-HV, nmol. $1^{-1}$ & $<0.05$ & $0.02 \pm 0.02$ & $0.03 \pm 0.03$ \\
\hline Renal extraction, \% & 0 & $19.7 \pm 2.0$ & $8.0 \pm 0.3$ \\
\hline Hepatic extraction, $\%$ & 0 & $2.5 \pm 2.7$ & $1.0 \pm 1.4$ \\
\hline Renal plasma flow, $\mathrm{ml} \cdot \mathrm{min}^{-1}$ & $873 \pm 52$ & $875 \pm 43$ & $932 \pm 50$ \\
\hline Hepatic plasma flow, $\mathrm{ml} \cdot \min ^{-1}$ & $758 \pm 36$ & $696 \pm 29$ & $697 \pm 51$ \\
\hline
\end{tabular}

Renal plasma flow (RPF) was assessed by the amount of PAH infused at steady-state divided by the differences in concentration of PAH between the brachial artery and renal vein $\left(\mathrm{ml} \cdot \mathrm{min}^{-1}\right)$.

Renal plasma clearance of C-peptide was estimated as the product of the renal plasma flow and the renal extraction of $C$-peptide $\left(\mathrm{ml} \cdot \mathrm{min}^{-1}\right)$.

Renal uptake of C-peptide was determined by the product of $\mathrm{RPF}$ and the difference in concentration of C-peptide between the brachial artery and the renal vein $\left(\mathrm{pmol} \cdot \mathrm{min}^{-1}\right)$.

Hepatic plasma flow was calculated as the amount of indocyanin green administered divided by the difference in concentrations of the dye between the artery and hepatic vein $\left(\mathrm{ml} \cdot \mathrm{min}^{-1}\right)$ at steadystate.

Hepatic extraction of $\mathrm{C}$-peptide was assessed as the difference between the concentrations of C-peptide in the brachial artery and hepatic vein divided by that in the brachial artery (\%).

Hepatic plasma clearance was calculated as the product of hepatic plasma flow and hepatic extraction of C-peptide $\left(\mathrm{ml} \cdot \mathrm{min}^{-1}\right)$.

Urinary excretion of C-peptide. The excretion of C-peptide was estimated by the product of urine production in ml per min and the concentration of C-peptide in urine $\left(\mathrm{pmol} \cdot \mathrm{min}^{-1}\right)$.

Glucose utilization. The amount of metabolized glucose during the last $40 \mathrm{~min}$ of each period was calculated by DeFronzo's method [23].

\section{Statistical analysis}

The paired $t$-test, Wilcoxon's non-parametric test and analysis of variance were used for the statistical analyses. Values are given as mean \pm SEM

\section{Results}

\section{C-peptide and glucose in plasma}

In 11 of the 13 patients the plasma C-peptide concentration (Table 2) was below the detection level of $0.05 \mathrm{nmol} \cdot \mathrm{I}^{-1}$ in the basal state. Two of the patients showed low concentrations at 0.12 and $0.14 \mathrm{nmol} \cdot \mathrm{l}^{-1}$. During the low-dose C-peptide infusion at steady-state the concentration was $0.81 \pm 0.10 \mathrm{nmol} \cdot 1^{-1}$. The corresponding value during the high-dose $\mathrm{C}$-peptide infusion was $2.33 \pm 0.30 \mathrm{nmol} \cdot \mathrm{l}^{-1}$ (Fig. 1 and Table 2). The plasma glucose concentration during the low-dose C- peptide infusion was $5.58 \pm 0.12 \mathrm{mmol} \cdot \mathrm{1}^{-1}$ and at the highdose C-peptide infusion $5.48 \pm 0.11 \mathrm{mmol} \cdot 1^{-1}$.

\section{Renal and hepatic exchange of C-peptide}

The renal uptake of C-peptide was $124 \pm 18 \mathrm{pmol} \cdot \mathrm{min}^{-1}$ with low-dose C-peptide infusion which increased to $155 \pm 21 \mathrm{pmol} \cdot \mathrm{min}^{-1}$ with high-dose C-peptide infusion $(p<0.05$, Fig. 2). The proportion of infused C-peptide that was taken up by the kidneys was $39 \pm 6 \%$ on the low-dose and decreased on the high-dose to $9 \pm 1 \%$ $(p<0.001)$. C-peptide fractional extraction was during low- and high-dose infusion periods $(19.7 \pm 2.0 \%$ and $8.0 \pm 0.3 \%$, respectively, $p<0.01$, Table 2 ). In the basal state and during the low- and high-dose C-peptide infusions no significant hepatic extraction of C-peptide was noted. The renal and hepatic plasma flows were stable both in the patients infused with C-peptide (Table 2) and in those given $\mathrm{NaCl}$ (data not shown).

\section{Urinary excretion of $C$-peptide}

The excretion of C-peptide was $7.3 \pm 2.1 \mathrm{pmol} \cdot \mathrm{min}^{-1}$ during the low-dose and increased $(p<0.01)$ to $33.6 \pm 5.8 \mathrm{pmol} \cdot \mathrm{min}^{-1}$ during the high-dose $\mathrm{C}$-peptide infusion period (Fig. 1). There was no significant difference between the proportion of C-peptide excreted and the amount administered in the low- and high-dose infusions $(3.4 \pm 0.7 \%$ vs $1.8 \pm 0.3 \%, N S)$. The proportions of the renal uptake of C-peptide which were excreted into the urine were $8 \pm 3 \%$ and $19 \pm 6 \%$, respectively (NS) on the low- and high-dose C-peptide infusions.

\section{Plasma glucagon, insulin and catecholamines}

The plasma arterial noradrenaline levels increased slightly $(p<0.05)$ from the basal to the low and high C-peptide infusions. A similar increase was found in the control group given $\mathrm{NaCl}$ instead of $\mathrm{C}$-peptide (Table 3 ). The

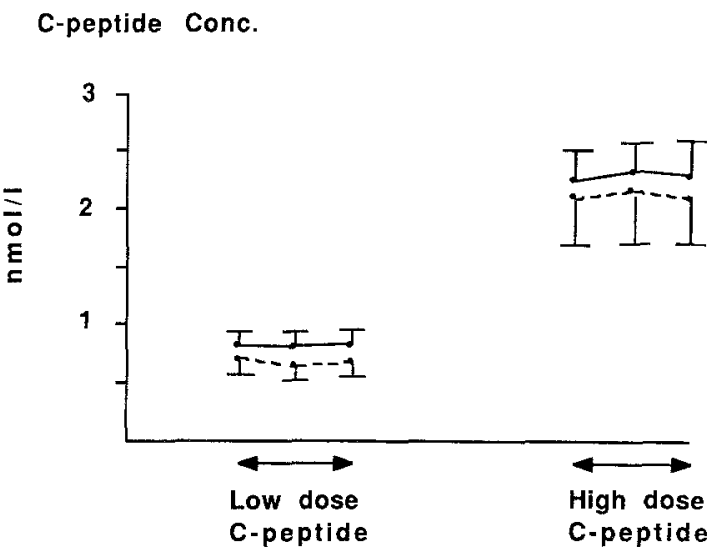

Fig. 1. Steady-state plasma levels of C-peptide in the artery ( - ) and renal vein (- . - ) during the last $15 \mathrm{~min}$ of each low$\left(5 \mathrm{pmol} \cdot \mathrm{kg}^{-1} \cdot \mathrm{min}^{-1}\right)$ and high-dose $\left(30 \mathrm{pmol} \cdot \mathrm{kg}^{-1} \cdot \mathrm{min}^{-1}\right)$ C-peptide infusion period 


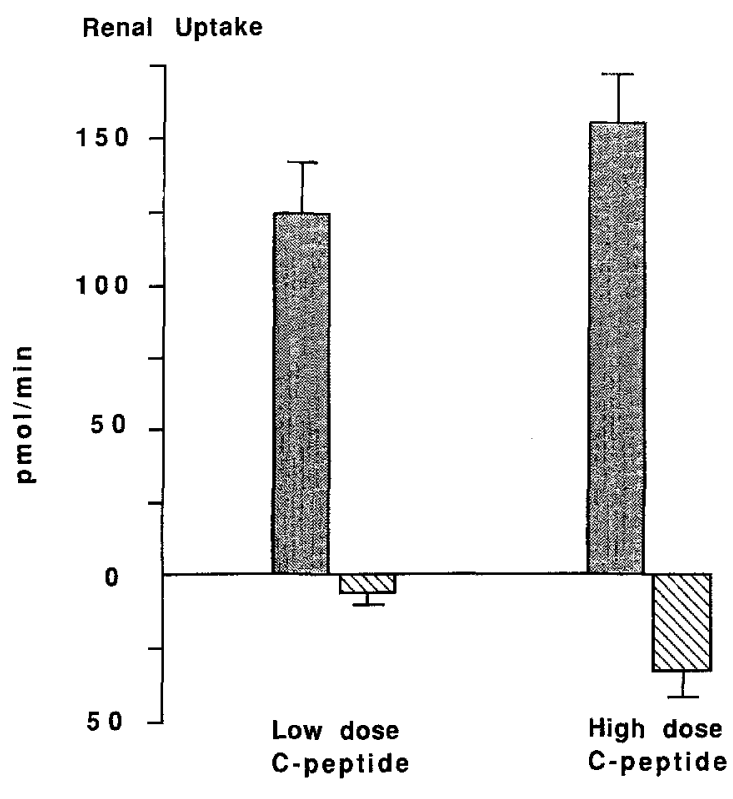

Urinary Excretion

Fig. 2. Renal uptake of C-peptide and urinary C-peptide excretion during low- $\left(5 \mathrm{pmol} \cdot \mathrm{kg}^{-1} \cdot \mathrm{min}^{-1}\right)$ and high-dose $(30 \mathrm{pmol}$. $\left.\mathrm{kg}^{-1} \cdot \min ^{-1}\right)$ C-peptide infusion periods

plasma glucagon concentration decreased slightly $(6 \%)$ $(p<0.05)$ from the basal to low- and high-dose C-peptide infusions, whereas the glucagon concentration remained about the same in the group infused with $\mathrm{NaCl}$ (Table 3 ). The plasma adrenaline concentration likewise remained at about the same level during the study and there was no significant difference between the two study groups (Table 3). The arterial plasma concentration of insulin was stable at levels of $19-23 \mu \mathrm{U} \cdot \mathrm{ml}^{-1}$ during the study. The levels were similar in the patients infused with C-peptide and with $\mathrm{NaCl}$, respectively.

\section{Glucose utilization and non-esterified fatty acids}

The utilization of glucose in the basal state was $1.89 \pm 0.21 \mathrm{mg} \cdot \mathrm{kg}^{-1} \cdot \mathrm{min}^{-1}$ and increased by $35 \%$ to $2.42 \pm 0.38 \mathrm{mg} \cdot \mathrm{kg}^{-1} \cdot \mathrm{min}^{-1}(p<0.02)$ during the lowdose C-peptide infusion $(n=13)$ and showed no further increase during the high-dose C-peptide infusion $(n=9)$, $2.58 \pm 0.28 \mathrm{mg} \cdot \mathrm{kg}^{-1} \cdot \mathrm{min}^{-1}$, which was higher than in the basal state $(p<0.05$, ANOVA). In the patients given $\mathrm{NaCl}$ instead of $\mathrm{C}$-peptide, the mean values were $2.05 \pm 0.28 \mathrm{mg} \cdot \mathrm{kg}^{-1} \cdot \mathrm{min}^{-1}$ in basal state $(n=7)$ and no significant change was observed during the $120 \mathrm{~min}$ of $\mathrm{NaCl}$ infusion $\left(2.22 \pm 0.29 \mathrm{mg} \cdot \mathrm{kg}^{-1} \cdot \mathrm{min}^{-1}\right.$ and $2.44 \pm 0.35 \mathrm{mg} \cdot \mathrm{kg}^{-1} \cdot \mathrm{min}^{-1}$, respectively). Serum NEFA were measured only in the C-peptide infusion group. The concentration decreased from $0.59 \pm 0.18 \mu \mathrm{mol} \cdot \mathrm{l}^{-1}$ in the basal state to $0.34 \pm 0.08 \mu \mathrm{mol} \cdot \mathrm{l}^{-1}(p<0.05)$ during the low-dose C-peptide infusion. No further significant decrease was noted during the high-dose C-peptide infusion although the levels were still lower than in basal state $\left(0.59 \pm 0.18 \mu \mathrm{mol} \cdot 1^{-1}\right.$ vs $\left.0.22 \pm 0.05 \mu \mathrm{mol} \cdot 1^{-1}\right)$.

\section{Discussion}

Altogether 14 Type 1 diabetic patients without severe microvascular lesions and with small or no residual insulin secretory activity were studied during normoglycaemia. We started our infusion of C-peptide, in similarity with Faber et al. [24], with a bolus infusion. A steady-state level of plasma C-peptide was observed in accordance with their results reached $40 \mathrm{~min}$ after the start of the constant rate of C-peptide infusion. However, despite a six-fold increase of the C-peptide infusion rate no more than a threefold increase of the plasma C-peptide levels was noted. These results indicate that the tissue uptake in our patients increased following the increased C-peptide infusion rate. Such a change in tissue uptake in humans has, to our knowledge not been demonstrated previously [25]. This is in contrast to the study by Polonsky et al. [25] which showed a ten-fold increase of the steady-state plasma level of C-peptide when the C-peptide infusion rate likewise was increased ten-fold. A recent experimental study has shown that C-peptide may increase the glucose transport into skeletal muscle of Type 1 diabetes [26]. A possible explanation for the increase in tissue uptake in the present study may be found in differences in the experimental procedures between the present and previous studies. The most substantial discrepancy in this respect was the constant insulin infusion given in our patients. The infusion of insulin corresponded to an amount of insulin secreted in the non-fasting state in non-diabetic subjects [27]. In accordance with the insulin infusion given we obtained a concentration in plasma free insulin at approximately $20 \mu \mathrm{U} \cdot \mathrm{ml}^{-1}$ i. e., nearly twice as high as that ordinarily observed in the fasting state in non-diabetic subjects [28]. Moreover, the blood glucose was kept normoglycaemic and stable with a variable infusion rate of glucose. In the Polonsky study [25] insulin was, in contrast to our study, infused at a variable rate simply to maintain the blood glucose level within the euglycaemic range. The concentration of insulin was not shown in their study, but it was probably lower than in the present report. Licinio-

Table 3. Plasma noradrenaline, adrenaline, glucagon, insulin and glucose in the 14 patients with Type 1 (insulin-dependent) diabetes participating in the C-peptide and/or $\mathrm{NaCl}\left(154 \mathrm{mmol} \cdot \mathrm{l}^{-1}\right)$ infusion study $\left(\mathrm{NaCl}=154 \mathrm{mmol} \cdot 1^{-1} \mathrm{NaCl}\right.$ infusion, $\mathrm{C}=\mathrm{C}$-peptide infusion). Mean \pm SEM are given

\begin{tabular}{lllll}
\hline & & $\begin{array}{l}\text { Baseline } \\
\text { values }\end{array}$ & Low dose & High dose \\
& $\mathrm{C}$ & $n=13$ & $n=13$ & $n=9$ \\
& $\mathrm{NaCl}$ & $n=7$ & $n=7$ & $n=6$ \\
\hline Noradrenaline $\left(\mathrm{nmol} \cdot \mathrm{1}^{-1}\right)$ & $\mathrm{C}$ & $1.18 \pm 0.17$ & $1.33 \pm 0.14^{\mathrm{a}}$ & $1.19 \pm 0.13^{\mathrm{b}}$ \\
& $\mathrm{NaCl}$ & $1.03 \pm 0.15$ & $1.25 \pm 0.24$ & $1.27 \pm 0.15^{\mathrm{b}}$ \\
Adrenaline $\left(\mathrm{nmol} \cdot \mathrm{l}^{-1}\right)$ & $\mathrm{C}$ & $0.89 \pm 0.15$ & $0.99 \pm 0.17$ & $0.88 \pm 0.15$ \\
& $\mathrm{NaCl}$ & $0.66 \pm 0.17$ & $0.72 \pm 0.15$ & $0.64 \pm 0.17$ \\
Glucagon $\left(\mathrm{pg} \cdot \mathrm{ml}^{-1}\right)$ & $\mathrm{C}$ & $56.7 \pm 2.4$ & $53.8 \pm 2.4^{\mathrm{a}}$ & $51.3 \pm 2.5^{\mathrm{b}}$ \\
& $\mathrm{NaCl}$ & $57.1 \pm 3.8$ & $54.8 \pm 5.2$ & $56.0 \pm 7.8$ \\
Insulin $\left(\mu \mathrm{U} \cdot \mathrm{ml}^{-1}\right)$ & $\mathrm{C}$ & $21.5 \pm 1.5$ & $23.2 \pm 1.6$ & $21.2 \pm 1.9$ \\
& $\mathrm{NaCl}$ & $19.8 \pm 1.5$ & $21.3 \pm 1.8$ & $21.8 \pm 1.3$ \\
Glucose $\left(\mathrm{mmol} \cdot \mathrm{l}^{-1}\right)$ & $\mathrm{C}$ & $5.65 \pm 0.16$ & $5.58 \pm 0.12$ & $5.48 \pm 0.11$ \\
& $\mathrm{NaCl}$ & $5.39 \pm 0.16$ & $5.68 \pm 0.06$ & $5.45 \pm 0.08$ \\
\hline
\end{tabular}

$p<0.05$ vs values in basal state (paired $t$-test); ${ }^{\mathrm{b}} p<0.05$ vs values in basal state (ANOVA) 
Paixao et al. [29] reported no change in tissue uptake of Cpeptide after ingestion of a meal. However, in contrast with our study it should be noted that the blood glucose was allowed to increase from $5.8 \mathrm{mmol} / 1$ to $18.7 \mathrm{mmol} \cdot 1^{-1}$ without supplying additional insulin.

The renal uptake with low dose accounted for $39 \%$ of the infused amount of C-peptide and decreased to $9 \%$ on the high dose infusion $(p<0.001)$. The renal plasma flow did not change during the study. The decreased renal fractional extraction may indicate that the limit of the transport capacity of the kidney for C-peptide uptake was reached even at the lower infusion rate. Moreover, in the present study the proportion of C-peptide degraded in the kidneys before excretion into urine was fairly constant at $80-90 \%$, which is in line with the results of Zavaroni et al. [1]. The renal metabolic pathway for C-peptide is not well known. However, in an experimental study it has been postulated that a peritubular extraction of C-peptide exsists [30]. Type 1 diabetes is often associated with a glomerular hyperfiltration [31], however, in a recent study [32] the urinary C-peptide excretion has not been found to correlate with the degree of renal hyperfiltration. It has previously been reported that about $2-5 \%$ of secreted Cpeptide is excreted into urine [4-6]. These reports were confirmed in the present study in which $2-3 \%$ of the infused amount of C-peptide was shown to be excreted into the urine.

There was no significant hepatic extraction of C-peptide during either the low or the high dose infusion. These results confirm an earlier report from a study in dogs that the liver metabolism of C-peptide is of little or no importance for the total metabolism of C-peptide [8].

C-peptide infusion was accompanied by an increased requirement for exogenous glucose infusion in order to maintain plasma glucose levels. This became apparent even at the low dose infusion with no further change during high dose administration. The extent to which this finding reflects an increased glucose utilization or a suppression of endogenous hepatic glucose production cannot be determined from the present data. Since insulin levels were unchanged and stable from the basal state and throughout the study it is unlikely that the finding reflects an insulin effect. The study design allows paired comparison between the results for the six subjects who received both C-peptide and $\mathrm{NaCl}$ infusion. Such a comparison demonstrates a significantly greater glucose utilization $(p<0.05)$ during $\mathrm{C}$-peptide infusion compared to $\mathrm{NaCl}$ administration, thereby supporting the notion that C-peptide may exert an influence on glucose homeostasis. An insulin-like effect of C-peptide is also suggested by the finding that NEFA levels decreased during C-peptide infusion, suggesting an antilipolytic effect. In our patients receiving C-peptide there was a small but significant decrease in the plasma glucagon from basal to low and high C-peptide infusion. The plasma glucagon levels showed no change in the seven patients receiving $\mathrm{NaCl}$ infusion alone. Hypothetically this may be an insulin-like effect of the C-peptide molecule per se, which has been suggested by the results of experimental studies $[13,26,34]$ and has also been given some support in humans [33]. An increase of plasma noradrenaline $(p<0.05)$ within normal levels in the group infused with C-peptide was observed from basal to low-dose C-peptide infusion with no further increase on the high dose. In the patients infused with $\mathrm{NaCl}$ alone noradrenaline increased from basal to the $120 \mathrm{~min}$ infusion. In summary, the plasma levels of C-peptide increased three-fold when the amount of C-peptide infused was increased six-fold from a low dose infusion. Renal uptake increased only slightly from the low-to high-dose Cpeptide infusion. Approximately $2-3 \%$ was excreted into the urine during both infusion periods. Little or no uptake by the splanchnic vascular bed was found. Thus, it is suggested that the tissue uptake of C-peptide may increase with an increased infusion of C-peptide. The results merit further investigation concerning a biological effect of $\mathrm{C}$ peptide in Type 1 diabetic patients.

Acknowledgements. We thank Ms. K. Föjer, Ms. K. Henriksson, Ms. E. Bauge for their skillful work. We also wish to express our gratitude to the Swedish Diabetes Association and the Karolinska Institute for financial support of the study.

\section{References}

1. Zavaroni J, Deferrari G, Lugari R et al. (1978) Renal metabolism of C-peptide in man. J Clin Endocrinol Metab 65:401-403

2. Henriksen JH, Tronier B, Bulow JB (1987) Kinetics of circulating insulin, $\mathrm{C}$-peptide and proinsulin in fasting nondiabetic man. Metabolism 36: 463-468

3. Regeur L, Faber OK, Binder C (1978) Plasma C-peptide in uremic patients. Scand J Clin Lab Invest 38:771-775

4. Horwitz DL, Rubenstein AH, Katz AI (1977) Quantitation of human pancreatic beta-cell function by immunoassay of C-peptide in urine. Diabetes 26:30-35

5. Meistas MT, Zadik Z, Margolis S, Kowarski AA (1981) Correlation of urinary excretion of C-peptide with the integrated concentration and secretion rate of insulin. Diabetes 30: 639-643

6. Meistas MT, Rendell M, Margolis S, Kowarski AA (1982) Estimation of the secretion rate of insulin from the urinary excretion rate of C-peptide: study in obese and diabetic subjects. Diabetes 31: $449-453$

7. Rubenstein AH, Pottenger LA, Mako M, Getz GS, Steiner DF (1972) The metabolism of proinsulin and insulin by the liver. J Clin Invest 51: 912-921

8. Polonsky K, Jaspan JB, Pugh W et al. (1983) Metabolism of C-peptide in the dog: in vivo demonstration of the absence of hepatic extraction. J Clin Invest 72: 1114-1123

9. Faber OK, Binder C (1979) C-peptide response to glucagon. Diabetes 26: 22-29

10. Kitabchi AE (1970) The biological and immunological properties of pork and beef insulin, proinsulin and connecting peptides. J Clin Invest 49: 979-987

11. Dunbar JC, McLaughlin WJ, Walsh MF, Foa PP (1977) Insulin secretion and glucose uptake by isolated islets of the hamster. Effect of insulin, proinsulin and C-peptide. Hormon Metab Res 8: $1-6$

12. Hagen C, Faber OK, Binder C, Alberti KGMM (1977) Lack of metabolic effect of C-peptide in normal subjects and juvenile diabetic patients. Acta Endocrinol 85 [Suppl.]: 209: 29

13. Wallberg-Henriksson H, Andréasson K, Galuska D, Johansson B-L, Thörne A, Sonnenfeld T (1989) C-peptide stimulates glucose transport in incubated normal muscle but not in muscle from Type 2 (non-insulin-dependent) diabetic patients. Diabetologia 32: 555 (Abstract)

14. Heding LG (1975) Radioimmunological determination of human C-peptide in serum. Diabetologia 11: 541-548 
15. Sjöberg S, Gunnarsson R, Gjötterberg M, Lefvert A-K, Persson A, Östman J (1987) Residual insulin production, glycaemic control and prevalence of microvascular lesions and polyneuropathy in long-term Type 1 (insulin-dependent) diabetes. Diabetologia 30: 208-213

16. Trivelli LA, Rawney HM, Lai H-T (1971) Haemoglobin components in patients with diabetes mellitus. N Engl J Med 284: 353 357

17. Faloona GR, Unger RH (1974) In: Glucagon Jaffe BM, Behrman HR (eds) Methods of hormone radioimmunoassay. Academic Press, New York London, pp 317-330

18. Hjemdal P, Odeskog H, Kahan T (1979) Determination of plasma catecholamines by high performance liquid chromatography with electrochemical detection; comparison with a radioenzymatic method. Life Sciences 25: 131-138

19. Arnquist H, Olsson P-O, von Schenck H (1987) Free and total insulin determined after precipitation with polyethylene glycol: analytic characteristics and effects of sample handling and storage. Clin Chem 33:93-96

20. Hagenfeldt L (1966) A gas chromatographic method for the determination of individual free fatty acids in plasma. Clin Chim Acta 13:266-268

21. Smith HW, Finkelstein N, Aliminosa L, Crawford B, Graber M (1945) The renal clearance of substituted hippuric acid derivation and other aromatic acids in dog and man. J Clin Invest 24 : $388-404$

22. Rowell LB, Blackmon JR, Bruice RA (1964) Indocynanin green clearance and estimated hepatic blood flow during mild to maximal exercise in upright man. J Clin Invest 43: 1677-1690

23. De Fronzo RA, Tobin JD, Reubin A (1979) Glucose clamp technique: a method for quantifying insulin secretion and resistance. Am J Physiol 237: E214-E223

24. Faber OK, Hagen C, Binder C (1978) Kinetics of human connecting peptide in normal and diabetic subjects. J Clin Invest 62 : 197-203

25. Polonsky KS, Liciano-Paixao J, Given BD et al. (1986) Use of biosynthetic human C-peptide in the measurements of insulin secretion rates in normal volunteers and type I diabetic patients. $J$ Clin Invest 77:98-105
26. Zierath JR, Thörne A, Johansson B-L, Wallberg-Henriksson H (1990) C-peptide stimulates the glucose transport in Type 1 diabetic skeletal muscle. Diabetes 39 [Suppl. 1]: $141 \mathrm{~A}$

27. Eaton RP, Allen RC, Schade DS (1983) Hepatic removal of insulin in normal man: dose response to endogenous insulin secretion. J Clin Endocrinol Metab 56: 1294-1300

28. Genuth SM (1973) Plasma insulin and glucose profiles in normal, obese and diabetic persons. Ann Intern Med 79: 812-822

29. Licinio-Paixao J, Polonsky KS, Given BD, Pugh W, Ostrega D (1986) Ingestion of a mixed meal does not affect the metabolic clearance rate of biosynthetic human C-peptide. J Clin Endocrinol Metab 63: 401-403

30. Rabkin R, Ross BD, Mako ME, Rubenstein AH (1987) The handling of insulin, proinsulin and C-peptide by the isolated rat kidney. Diabetes 27 [Suppl 1]: 192-196

31. Mogensen CE, Andersen MJF (1973) Increased kidney size and glomerular filtration rate in early juvenile diabetes. Diabetes 22 : 706-712

32. Huttunen N-P, Knip M, Käär M-L, Puukka R, ̊kkerblom HK (1989) Clinical significance of urinary C-peptide excretion in children with insulin-dependent diabetes mellitus. Acta Paediatr Scand 78: 271-277

33. Hoogwerf BJ, Bantle JP, Gaensten HE et al. (1986) Infusion of synthetic human C-peptide does not affect plasma glucose, serum insulin or plasma glucagon in healthy subjects. Metabolism 35: $122-125$

34. Wojcikowski CZ, Maier V, Dominiak K, Fussgänger R, Pfeiffer EF (1983) Effects of synthetic rat C-peptide in normal and diabetic rats. Diabetologia 25:288-290

Received: 16 May 1990

and in final revised form: 12 February 1991

Dr. S.Sjöberg

Department of Medicine

Huddinge Hospital

S-141 86 Huddinge

Sweden 